\title{
Genetic Transfer of Salmonella O Antigens to Escherichia coli $\mathrm{O8}$
}

\author{
By W. KIEFER, G. SCHMIDT, BARBARA JAN N AND K. JANN \\ Max-Planck-Institut für Immunbiologie, D-78 Freiburg i.Br., Germany
}

(Received 25 June 1975; revised 5 August 1975)

\begin{abstract}
SUMMARY
His $^{+}$hybrids from a cross between a Salmonella typhimurium donor and an Escherichia coli $\mathrm{O} 8$ recipient expressed $E$. coli $\mathrm{O} 8$ specificity and in addition Salmonella $\mathrm{O}_{4}, \mathrm{I} 2$-specificity. This indicated that the recipients had received the his-linked donor $r f b$ cluster determining the synthesis of $S$. typhimurium Ospecific repeat units and that the $r f b$ genes of both mating partners are functional in these hybrids. Chemical analyses showed that the hybrids contained an $E$. coli O8 lipopolysaccharide (O antigen) and a $S$. typhimurium specific lipopolysaccharide with only one $\mathrm{O}$-specific repeat unit (SR antigen).

O8-negative mutants selected from the O8-positive hybrids retained the Salmonella $\mathrm{O}$-specificity and represent semi-rough (SR) forms, because the $r f c$ gene(s) determining the polymerization of repeat units has not been transferred. Attempts to introduce the $S$. typhimurium $r f c$ locus into $E$. coli $O 8$ remained unsuccessful.

Crosses between a $S$. typhi donor and E. coli O8 gave rise to smooth (S) and SR $\mathrm{His}^{+}$recombinants exhibiting only $S$. typhi $\mathrm{O}$-specificity. The smooth recombinants are assumed to have obtained the his-linked $r f b$ cluster and in addition the $r f c$ gene(s) of the donor. The exchange of the $r f b$ region of such smooth recombinants by that of a $S$. typhimurium donor led to smooth hybrids with $\mathrm{O}_{4},(5), 12$-specificity.

The phenotypically smooth recombinants exhibited concomitantly S- and SRlipopolysaccharides of $S$. typhi and $S$. typhimurium O-specificity, respectively.
\end{abstract}

\section{INTRODUCTION}

The polysaccharide portion of the O-antigenic lipopolysaccharide (LPS) of Enterobacteriaceae consists of two regions, the basal or core oligosaccharide (LPS core) and the O-specific chains composed of repeating oligosaccharide units (Lüderitz et al., 197 I).

The composition and structure of O-specific chains vary widely among the different serotypes whereas the LPS core is less variable. Thus all Salmonella serotypes are thought to have an identical core structure. On the other hand four different core types (RI to R4) have been identified thus far in Escherichia coli and Shigella (Schmidt, Jann \& Jann, 1969, 1974; Mayer \& Schmidt, 1973).

The genetic background of the LPS synthesis has mainly been studied with Salmonella typhimurium. These investigations have shown that most of the genes responsible for core synthesis ( $r f a$ genes) are clustered in the $c y s E-p y r E$ region of the chromosome, whereas the genes determining the synthesis of $\mathrm{O}$-specific repeat units form a cluster ( $r f b$ genes) closely linked to the histidine (his) operon. The polymerization of repeat units is under the control of the $r f c$ gene(s) which is located outside the main $r f a$ and $r f b$ clusters, adjacent to the $t r p$ operon (Stocker \& Mäkelä, I97I). A defect in the $r f c$ region leads to SR mutants which can attach only single unpolymerized repeat units to the core.

The repeat unit of $S$. typhimurium determined by the $r f b$ cluster represents an abequosylmannosyl-rhamnosyl-galactose oligosaccharide (Lüderitz et al., I97I), corresponding 
Table I. Characteristics of bacterial strains

\begin{tabular}{|c|c|c|c|c|}
\hline Strain & Serotype & $\begin{array}{l}\text { Auxotrophic } \\
\text { markers }\end{array}$ & $\begin{array}{l}\text { Carbohydrate } \\
\text { utilization }\end{array}$ & $\begin{array}{l}\text { Respon } \\
\text { strepton }\end{array}$ \\
\hline \multicolumn{5}{|l|}{ Donors } \\
\hline S. typhimurium Hfrk9 & 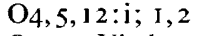 & $t h r$ & $l a c^{-}$ & $\mathrm{s}$ \\
\hline S. typhi WR4000 & $\mathrm{O} 9, \mathrm{I} 2, \mathrm{Vi}: \mathrm{d}$ & cys trp & $r h a^{-}$ara $^{-} x y l^{-}$ & s \\
\hline \multicolumn{5}{|l|}{ Recipients } \\
\hline E. coli $\mathrm{F} 210$ & $\mathrm{O} 8: \mathrm{K}^{-*}: \mathrm{H}^{-}$ & met pro his trp & $m t^{-}$ara $^{-}$ & $\mathrm{r}$ \\
\hline E. coli $\mathrm{F} 464$ & $\mathrm{O} 8: \mathrm{K}^{-}: \mathrm{H}^{-}$ & met pro his & $\mathrm{mtl}^{-} \mathrm{ara}^{-}$ & \\
\hline
\end{tabular}

thr, threonine; cys, cysteine; trp, tryptophan; met, methionine; pro, proline; his, histidine; lac, lactose; rha, rhamnose; ara, arabinose; $x y l$, xylose; $m t l$, mannitol; s, sensitive; $r$, resistant.

serologically to the $\mathrm{O}$ antigen 4 and at least to parts of the I 2 antigen complex (Mäkelä, I966; Stocker \& Mäkelä, I97I). In addition, the O chain of $S$. typhimurium is modified by $O$-acetylation of abequose (factor $\mathrm{O}_{5}$ ) and by the attachment of a glucose branch in $\alpha-\mathrm{I}, 4$ linkage to the galactose unit. The glucosylation is serologically reflected in the appearance of the OI $2_{2}$ factor, a sub-component of the $\mathrm{O} 12$ antigen complex. The genetic determinants (oaf genes) responsible for these modifications are located outside the $r f b$ cluster (Stocker \& Mäkelä, 1971; Mäkelä, I973). The expression of the Or factor results from a conversion of the glucose-galactose linkage from $\alpha-I, 4$ into $\alpha-\mathrm{I}, 6$, depending on the presence of the lysogenizing phage P22 (Stocker \& Mäkelä, 197I).

Genes equivalent in site and function to the Salmonella $r f a$ and $r f b$ genes could also be demonstrated in E. coli (Ørskov \& Ørskov, 1962; Schmidt, Jann \& Jann, 1970).

Jones, Koeltzow \& Stocker (1972) reported experiments involving the transfer of the Salmonella $r f b$ cluster into $E$. coli KI2. They showed that the Salmonella $r f b$ genes are maintained but not expressed in E. coli KI 2 unless the KI 2 LPS core is modified by the introduction of Salmonella $r f a$ genes. Apparently, the KI 2 LPS core cannot accept Salmonella O-specific units. Hämmerling et al. (1971) obtained E. coli hybrids with Salmonella O-specificity from crosses between a Salmonella abony donor and an E. coli Oroo recipient. One reason for the difference in the capacity to express Salmonella $O$ factors may be the presence of different LPS core structures in the above-mentioned $E$. coli recipients. Thus the E. coli Oroo LPS core (R2) resembles that of Salmonella (Hämmerling et al. 1971), while the $E$. coli K 2 core is distinct from both these core types (Schmidt, I973).

Our interest was focused on $E$. coli hybrids expressing Salmonella O-specificity since they may be the basis for the development of an effective avirulent live vaccine against typhoid. The main purpose of our investigations was the introduction of Salmonella $r f b$ and $r f c$ genes into $E$. coli $\mathrm{O} 8$ and the characterization of the resulting hybrids.

\section{METHODS}

Bacteria. The following strains were used: Salmonella typhimurium Hfrk9 (Sanderson et al. 1972) and S. typhi wr4000 (Johnson, Falkow \& Baron, 1964) as donors, and the E. coli $\mathrm{O} 8$ strains F2 IO and F464 as recipients. The characteristics of the bacterial strains used are given in Table $\mathrm{I}$. The $E$. coli $\mathrm{O} 8$ strains are $\mathrm{K}^{-}$derivatives of $E$. coli $\mathrm{E} 56\left(\mathrm{O} 8: \mathrm{K}_{27}: \mathrm{H}^{-}\right)$ having a LPS core of the RI type (Schmidt et al. 1969).

Media. For minimal agar, $25 \mathrm{~g}$ Difco-Bacto agar and $0.75 \mathrm{~g}$ sodium citrate $.5 \mathrm{H}_{2} \mathrm{O}$ were mixed in I 1 distilled water and sterilized (solution I). A salt solution sterilized separately, contained (g/l distilled water): $\mathrm{NH}_{4} \mathrm{Cl}, 2 \mathrm{O} ; \mathrm{NH}_{4} \mathrm{NO}_{3}, 4 ; \mathrm{Na}_{2} \mathrm{SO}_{4}, 8 ; \mathrm{K}_{2} \mathrm{HPO}_{4}, \mathrm{I} 2 ; \mathrm{KH}_{2} \mathrm{PO}_{4}, 4$; 
$\mathrm{MgSO}_{4}, 0.4$ (solution 2). Then $900 \mathrm{ml}$ solution I and $300 \mathrm{ml}$ solution 2 were mixed together and glucose, separately sterilized, was added to a final concentration of $0.3 \%$. Recombinants from matings between $S$. typhimurium and $E$. coli were selected on minimal agar containing lactose instead of glucose. Selection of recombinants from crosses with the $S$. typhi donor WR4000 was performed on selective minimal agar, which was minimal agar plus $400 \mu \mathrm{g}$ streptomycin $/ \mathrm{ml}$. Amino acids for supplementation of minimal agar were added to a final concentration of $20 \mu \mathrm{g} / \mathrm{ml}$.

Merck Standard I broth and DI,5-agar (Schlecht \& Westphal, I966) were used as complete media.

Mating experiments. Donor and recipient strains freshly grown in broth were mixed in such a way that approximately $5 \times 10^{7}$ donor cells and $5 \times 10^{8}$ recipient cells $/ \mathrm{ml}$ were present in the mixture. The mating mixture was incubated for $4 \mathrm{~h}$ at $37{ }^{\circ} \mathrm{C}$ without agitation and then centrifuged. The sediment was suspended in sterile water and appropriately diluted. Portions (O. I ml) were plated on selective minimal agar and the agar plates incubated at $37^{\circ} \mathrm{C}$ for $48 \mathrm{~h}$. Recombinant colonies were first transferred on to the same medium used for selection and then streaked on to complete agar from which single colonies were isolated.

Bacteriophages. For the characterization of bacterial strains the following bacteriophages were used: P22, P22c2, 88, Felix O-I (FO), C2I and 6SR. Phage P22 (Zinder, I953; Wilkinson, Gemski \& Stocker, I 972) attacks smooth Salmonella strains with O antigen I2. $\mathrm{P}_{22 c 2}$ is a non-lysogenizing clear plaque mutant of $\mathrm{P}_{22}$. The FO phage (Kallings, 1967) lyses smooth (S) strains of most Salmonella serotypes and also rough (R) forms having the complete Salmonella LPS core (Lindberg, 1967). The C2I phage is active on certain rough mutants of Salmonella and E. coli (Lindberg, 1973) and on smooth E. coli O8 and other serotypes possessing the LPS core of the RI type (G. Schmidt, unpublished observation). The phage 6SR, known as 'anti-rough' phage (Kay, 1962) lyses Salmonella and E. coli rough mutants. Phage $\Omega 8$ specifically attacks strains with the E. coli $\mathrm{O} 8$ antigen (Jann et al., I97I).

The phages were propagated on suitable hosts in broth (Adams, I959) and stored over chloroform at $4{ }^{\circ} \mathrm{C}$. To determine the susceptibility of bacterial strains towards phages, drops of the lysates containing about $\mathrm{IO}^{\gamma}$ plaque-forming units $/ \mathrm{ml}$ were deposited on to bacterial lawns on agar plates. The phage reaction was scored after overnight incubation at $37^{\circ} \mathrm{C}$.

Serological methods. Antisera against S. typhimurium $\left(\mathrm{O}_{4}, 5, \mathrm{I} 2\right)$ and $S$. typhi $\left(\mathrm{O} 9, \mathrm{I}_{2}, \mathrm{I}_{2}\right.$,

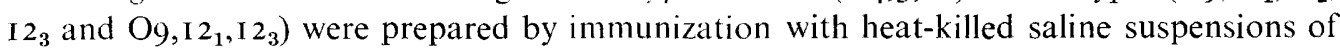
agar cultures. The following Salmonella factor sera, kindly supplied by Dr S. Schlecht of this Institute, were used: anti-O 4 , anti-O5, and anti-O I $2_{2}$. An anti-O9, I $2_{3}$ serum was obtained by absorption of an anti-O $9,12_{1}, 12_{2}, \mathrm{I}_{3}$ serum with $S$. reading $\left(\mathrm{O}_{4}, \mathrm{I}_{1}, 12_{2}\right)$.

The presence of $\mathrm{O}$-antigenic factors was determined by slide agglutination using antisera diluted $\mathrm{I}: 5 \mathrm{in} 0.2 \% \mathrm{NaCl}$ instead of $0.9 \%$, to avoid spontaneous agglutination of rough and semi-rough (SR) mutants.

Isolation and purification of lipopolysaccharides. The lipopolysaccharides were extracted from whole bacteria using a mixture of $90 \%$ phenol and water $(\mathrm{I}: \mathrm{I}, \mathrm{V} / \mathrm{r})$ at $68{ }^{\circ} \mathrm{C}$ for $5 \mathrm{~min}$ as described by Lüderitz et al. (I 97I) and purified by repeated ultracentrifugation. The final sediment was dissolved in water and freeze-dried. At that stage of purification the lipopolysaccharides were obtained in yields of $\mathrm{I}$ to $2 \%$ based on the dry weight of the cells.

Fractionation of the lipopolysaccharides. The fractionation of lipopolysaccharide by mild acid hydrolysis has been described (Müller-Seitz, Jann \& Jann, I968; Schmidt et al., 1969). 
In short, the lipopolysaccharides ( $100 \mathrm{mg} / \mathrm{ml}$ ) were hydrolysed at $100{ }^{\circ} \mathrm{C}$ for $90 \mathrm{~min}$ in $\mathrm{I} \%$ $(\mathrm{v} / \mathrm{v})$ acetic acid. This splits off lipid $\mathrm{A}$, which was removed by centrifugation. The supernatant fractions containing the polysaccharide moiety of the lipopolysaccharides were freeze-dried. For further purification of the polysaccharides the freeze-dried materials were dissolved in small amounts of pyridine-acetic acid-water (I0:4:886, by vol.) applied to columns of Sephadex G50 and eluted with the same solvent mixture. The eluants were monitored with a phenol-sulphuric acid reagent according to Dubois et al. (I955). From the peaks the corresponding materials were obtained by freeze-drying. They were then analysed further.

Analytical procedures. Sugars were identified by thin-layer chromatography of the neutralized hydrolysates $\left(0.5 \mathrm{M}-\mathrm{H}_{2} \mathrm{SO}_{4}\right.$ at $100{ }^{\circ} \mathrm{C}$ for $\left.4 \mathrm{~h}\right)$ of lipopolysaccharides on cellulose plates (Merck), with butanol-pyridine-water $(6: 4: 3$, by vol.) as solvent. Spots were detected with alkaline silver nitrate.

Quantitative sugar analyses were performed using gas-liquid chromatography of peracetylated alditols following the method of Holme et al. ( I968). A Varian aerograph series 1520 was used with ECNSS-M (3\% 100-120 Gaschrom Q) as a stationary phase. Temperature was $180^{\circ} \mathrm{C}$. Glucosamine was determined with the Elson-Morgan reaction as modified by Strominger, Park \& Thompson (1959); abequose and tyvelose were determined by the thiobarbituric acid assay as modified by Waravdekar \& Saslaw (1959).

\section{RESULTS}

Introduction of the $S$. typhimurium $r f b$ region into $E$. coli $O 8$

Because the $r f b$ gene cluster of $S$. typhimurium is closely linked to the his operon (Stocker \& Mäkelä, I97I), His ${ }^{+}$recombinants were selected from crosses of a S. typhimurium donor and E. coli $\mathrm{F} 210(\mathrm{O} 8)$ on suitably supplemented minimal agar with lactose as sole carbon source, for counterselection of the lac- Salmonella donor. As donor, S. typhimurium Hfrk9 was used, which transfers the his locus as a leading marker (Sanderson et al., 1972). The cross is presented in scheme I (Fig. 1). The frequency of $\mathrm{His}^{+}$hybrids was approximately $10^{-6} /$ donor cell, but most of the $\mathrm{His}^{+}$hybrids were rather unstable and segregated His- clones. After repeated single colony isolations on the selective minimal medium used for primary isolation, ten stable His ${ }^{+}$hybrids (F961 to F970) were finally obtained, which had retained the pro met trp ara markers of the $E$. coli recipient. With one exception they were also mannitol non-fermenters, like $E$. coli f2Io.

The hybrids could not be agglutinated in $0.3 \%$ auramine or in $3.5 \%(\mathrm{w} / \mathrm{v}) \mathrm{NaCl}$ and formed homogenous suspensions even after heating at $100{ }^{\circ} \mathrm{C}$ for $\mathrm{I} h$. Thus the His ${ }^{+}$hybrids behaved like smooth enterobacteria. In slide tests the hybrids were strongly agglutinated in anti-O8 serum. In addition, they showed a weak reaction in Salmonella factor- $\mathrm{O}_{4}$ antiserum.

The occurrence of Salmonella O4-specificity indicates that the his-linked $r f b$ region had been introduced from the donor into the respective recipients. The concomitant expression of $E$. coli and Salmonella O-specificity suggests that the intact $r f b$ genes of both the recipient (O8) and the donor $\left(\mathrm{O}_{4}\right)$ coexisted in these hybrids. Of the ten hybrids, two (F969, F970) were also slightly agglutinated in Salmonella factor-O5 antiserum, indicating the presence of Salmonella $\mathrm{O}_{5}$ factor. Therefore these two hybrids must also have inherited the donor oaf $A$ locus (the genetic determinant of the $\mathrm{O}_{5}$ factor) which is located near to the $r f b$ cluster (Stocker \& Mäkelä, 1971). Thus two serologically different hybrid types were selected, as presented in Fig. 1. 


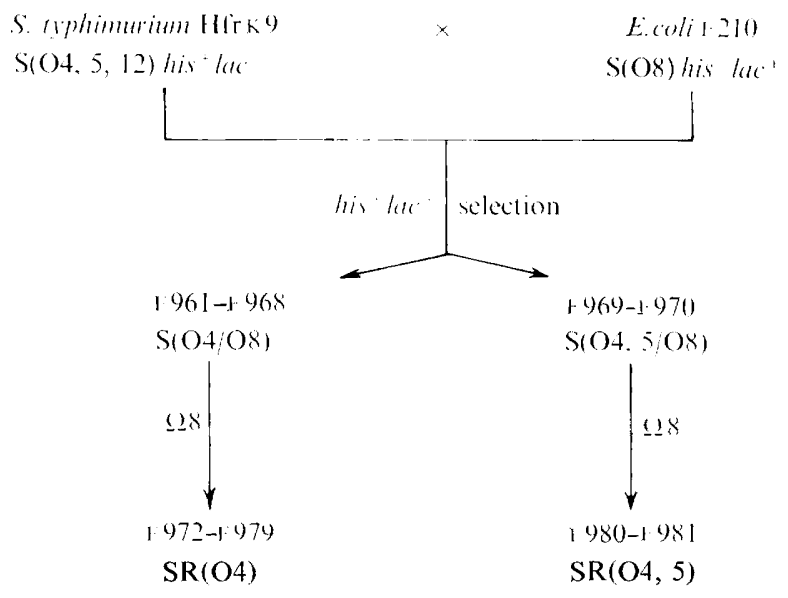

Fig. 1. Scheme 1. S, smooth; SR, semi-rough.

Table 2. Phage sensitivity, antigen patterns and mannitol utilization of O8-negative $\mathrm{His}^{+}$hybrids

\begin{tabular}{|c|c|c|c|c|c|c|c|c|}
\hline \multirow[b]{2}{*}{$\begin{array}{l}\text { Strain } \\
\text { designation* }\end{array}$} & \multicolumn{8}{|c|}{ Action of phage? } \\
\hline & $\begin{array}{l}\text { Antigen } \\
\text { pattern }\end{array}$ & 28 & $P_{22}$ & $\mathrm{P}_{22 \mathrm{C} 2}$ & $\mathrm{FO}$ & $\mathrm{C} 21$ & $6 \overline{\mathrm{SR}}$ & $\begin{array}{c}\text { Mannitol } \\
\text { utilization: }\end{array}$ \\
\hline \multicolumn{9}{|l|}{ Hybrids } \\
\hline F972-F979 & $\mathrm{O}_{4}, \mathrm{I} 2$ & - & - & - & - & + & - & - \\
\hline F980 & $\mathrm{O}_{4}, 5, \mathrm{I} 2$ & - & - & - & - & + & - & - \\
\hline F98 I & $\mathrm{O}_{4}, 5, \mathrm{I} 2$ & - & -- & - & + & - & 一 & + \\
\hline \multicolumn{9}{|l|}{ Parents } \\
\hline F210 & O8 & $t$ & - & - & - & + & - & - \\
\hline Hfrk9 & $\mathrm{O}_{4}, 5,12$ & - & + & + & + & - & - & + \\
\hline
\end{tabular}

* See Fig. 3. $\dagger+$, Lysis; - , no reaction. ++ , Fermentation; -, no fermentation.

Selection and properties of hybrids lacking E. coli $O 8$ antigen

Hybrids having only Salmonella O-specificities were obtained with the help of the O8specific phage $\Omega 8$. This phage lyses the O8-positive hybrids, and single $\Omega 8$-resistant colonies grown within the lysis zone were isolated from each of the hybrids (see Fig. I). For purification, single colony isolations were repeated several times. Slide agglutination tests revealed that the 128 -resistant mutants (F972 to F98I) derived from the S hybrids (F96I to F970) lacked the $E$. coli $\mathrm{O} 8$-specificity but had retained the antigen factors $\mathrm{O}_{4}$ and $\mathrm{O}_{4}, 5$, respectively, as indicated in Fig. I. They were also agglutinated in slide tests with antiserum against S. typhi $\left(\mathrm{O} 9,12_{1}, 12_{2}, \mathrm{I}_{3}\right)$ but were not reactive in $\mathrm{O}_{12} 2_{2}$ or in $\mathrm{O}_{9}, \mathrm{I}_{2}$-antiserum. This suggests that the hybrids only express the $\mathrm{O} 12_{1}$-specificity of the Salmonella $\mathrm{O} 12$ antigen complex. The O8-positive $\mathrm{S}$ hybrids also showed an agglutination reaction in the anti-O9, 12 sera used here. This seems to be based on an unilateral partial cross-specificity apparently existing between $E$. coli $\mathrm{O} 8$ and the Salmonella $\mathrm{O} 9$ factor. Thus cells of $E$. coli $\mathrm{O} 8$ are agglutinated in anti-Salmonella $\mathrm{O}_{9}$ serum but Salmonella bacteria containing $\mathrm{O}_{9}$ antigen are nonreactive in anti-E. coli $\mathrm{O} 8$ serum (unpublished observations; $M$. Heidelberger, personal communication).

Unlike the $S$ hybrids, all $\Omega 8$-resistant mutants therefrom were agglutinated in $3.5 \% \mathrm{NaCl}$. This is indicative of $\mathrm{R}$ as well of SR mutants (Hämmerling et al., I97I) and suggested that 
the O8-negative hybrids bearing Salmonella O-specificity represent SR-forms which can attach only single O-specific repeat units to the core. This was confirmed when the O8negative hybrid strains were tested with six S- and R-specific phages (see Table 2). The resistance to the R-specific phage 6SR and to the S-specific phage P22, which needs the presence of polymerized repeat units for adsorption, indicates that the mutants $F 972$ to F98 I resemble SR $r f c$ mutants of $S$. typhimurium (Wilkinson et al., I972).

From the sensitivity to phage C2 I we conclude that the hybrids $\mathrm{F} 972$ to F980 have the RI LPS core of $E$. coli O8 (Schmidt et al., I969). The FO-sensitivity of the hybrid F98 I indicates the presence of a Salmonella-like core (Lindberg, 1967), which means that this hybrid must have received donor $r f a$ genes together with the adjacent $m t^{+}$allele (see Table 2).

The strains $\mathrm{F}_{972}\left(\mathrm{O}_{4}, \mathrm{I} 2\right)$ and $\mathrm{F} 98 \mathrm{I}\left(\mathrm{O}_{4}, 5, \mathrm{I} 2\right)$ were used for the production of antisera in rabbits. In these antisera $\mathrm{O}_{4}$ and $\mathrm{O}_{1} 2$ antibodies could be demonstrated by agglutination of cells from $S$. typhimurium $\left(\mathrm{O}_{4}, 5, \mathrm{I} 2\right)$, S. essen $\left(\mathrm{O}_{4}, \mathrm{I}_{2}\right)$ and $S$. typhi $\left(\mathrm{O}_{9}, \mathrm{I} 2\right)$. In addition, $\mathrm{O}_{5}$ antibodies could be detected in anti-F98 I serum adsorbed with $S$. essen.

Thus the immunization experiments confirmed the presence of Salmonella $O$ factors in the hybrids.

The ability of the hybrids to express Salmonella O-specificity in consequence of the introduction of $S$. typhimurium $r f b$ genes suggests that Salmonella $\mathrm{O}$-specific repeat units can be attached to the RI LPS core of $E$. coli. The SR character of the $\Omega 8$-resistant mutants derived from the $\mathrm{S}\left(\mathrm{O}^{+}\right)$hybrids implies that the donor $r f c$ locus had not been transferred to the E. coli $\mathrm{O} 8$ recipient.

\section{Introduction of Salmonella $r f b$ and $r f c$ genes into E. coli $O 8$}

To obtain hybrids with the polymerized repeat units of $S$. typhimurium it was necessary to transfer the $r f c$ region, in addition to the $r f b$ cluster, into $E$. coli recipients. Attempts to transfer the $r f c$ gene(s) into O4-positive hybrids by selection of the adjacent trp region of appropriate Salmonella donors were unsuccessful, but this could be achieved indirectly with the help of Salmonella typhi-E. coli recombinants.

It was observed that the introduction of the his region from a S. typhi donor (WR4000) into $E$. coli $\mathrm{O} 8$ led to $\mathrm{SR}$ and $\mathrm{S}$ hybrids having $\mathrm{O} 9, \mathrm{I} 2$ antigen factors but lacking $E$. coli O8-specificity (Kiefer, I 974). From this we assumed that, in contrast to the $S$. typhimurium$E$. coli hybrids, in these recombinants the donor $r f b$ cluster has replaced the $r f b$ of the $E$. coli recipient. In addition the $S$ recombinants were presumed to have inherited the donor $r f c$ region.

The $r f c \cdot$ determined polymerase of $S$. typhi is also active on $S$. typhimurium O-repeat units, and vice versa (Mäkelä, 1965). Thus the introduction of $S$. typhimurium rfb genes into such smooth $S$. typhi-E. coli hybrids should lead to $\mathrm{S}$ forms with the serological specificity of S. typhimurium. Therefore the construction of S hybrids with $S$. typhimurium specificity was performed according to scheme 2 (Fig. 2). His $^{+}$recombinants from a cross of the S. typhi donor WR400O and E. coli $\mathrm{F} 464(\mathrm{O} 8)$ were selected on suitably supplemented minimal agar containing streptomycin $(400 \mu \mathrm{g} / \mathrm{ml})$ to counterselect donor cells. One of the smooth His hybrids (FIO08) with O9,I2-specificity was chosen for further experiments and was again provided with a defect in histidine synthesis $\left(\mathrm{His}^{-}\right)$by mutagen treatment. In addition, this smooth $\mathrm{His}^{-}(\mathrm{O} 9, \mathrm{I} 2)$ strain (FIO6r) does not synthesize methionine and proline (Met-Pro ${ }^{-}$) and does not ferment mannitol and arabinose like the original E. coli $\mathrm{F} 464$.

The hybrid strain F106I ( His $^{-}$) was used as recipient in a subsequent cross with $S$. typhimurium $\mathrm{HfrK} 9$, from which $23 \mathrm{His}^{+}$hybrids were selected on minimal-lactose agar supple- 


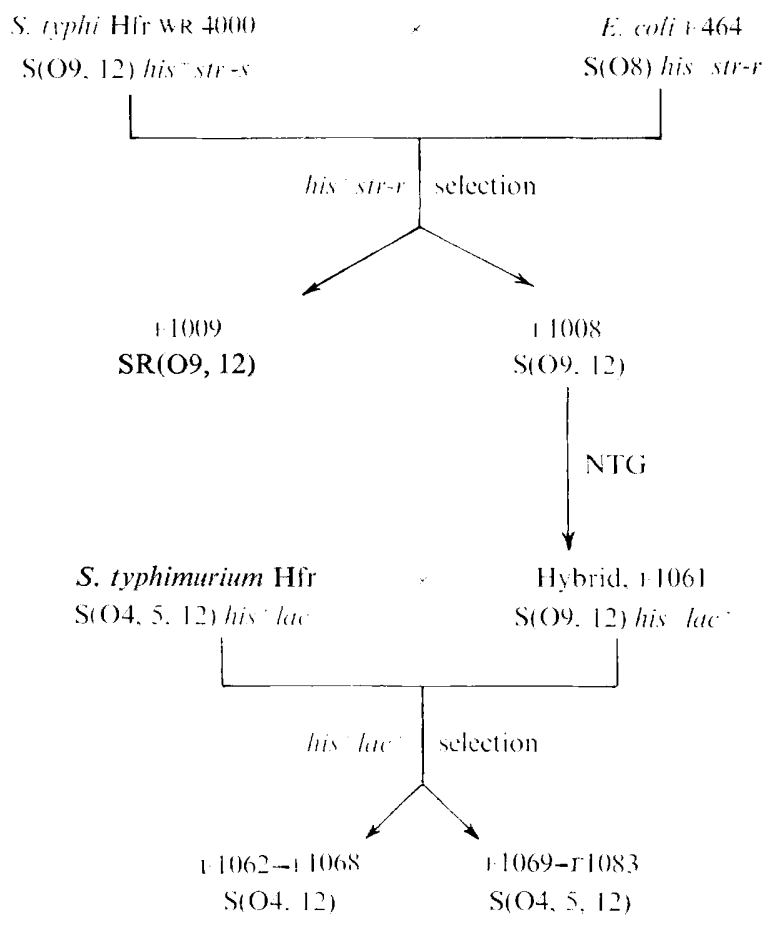

Fig. 2. Scheme 2. S, smooth; SR, semi-rough; NTG, treatment with the mutagen $N$-methyl- $N^{\prime}$-nitro- $N$-nitrosoguanidine.

mented with methionine and proline. The hybrids were purified by repeated single colony isolations. All recombinants had retained the markers pro met ara $\mathrm{mtl}$ and behaved like $\mathrm{S}$ forms. Thus when grown in nutrient broth at $37^{\circ} \mathrm{C}$ they formed stable suspensions which remained homogeneously turbid even after heating at $100{ }^{\circ} \mathrm{C}$ for $\mathrm{I} h$.

The hybrids were further characterized by slide agglutination tests using different antisera and by their sensitivity patterns towards smooth- and rough-specific phages. Twenty-two hybrid strains were agglutinated in anti-O 4 as well as in anti-O9, 12 serum but not in anti$\mathrm{OI}_{2}$ and anti-O9, $\mathrm{I}_{3}$ sera. This result shows that these recombinants possess the $\mathrm{O}_{4, \mathrm{I} 2}$ factors, evidently in consequence of the introduction of the his-linked donor $r f b$ genes. The smooth $\mathrm{O}_{4}, \mathrm{I} 2$-specific recombinants were not agglutinated by anti-Or $2_{2}$ and anti-O9, $12_{3}$ sera, which suggests that, like the SR hybrids, they possess only the Or $2_{1}$ determinant. One of the hybrids was reactive like the recipient $\mathrm{F}_{106} \mathrm{I}$ in anti-O9, $\mathrm{I} 2$ and anti-O9, 46 sera but not in anti- $\mathrm{O}_{4}$ serum, indicating that no exchange of the $\mathrm{rfb}$ region had taken place in this case. Of the 22 hybrids with $\mathrm{O}_{4}, \mathrm{I} 2$-specificity, 15 were also agglutinated in an anti-O5 serum, indicating the presence of the $\mathrm{O}$-factor 5 . Thus, these recombinants must have inherited the oaf $A$ gene in addition to the $r f b$ genes of the donor.

Two representative hybrids, one with $\mathrm{O}_{4}, \mathrm{I} 2$-specificity (FIO62) and one with $\mathrm{O}_{4}, 5$, 12 specificity (FI069) were chosen for further investigations and for production of antisera in rabbits.

Absorption and agglutination tests with these sera confirmed the presence of the abovementioned antigen factors in these recombinants. The $\mathrm{O}$-antigen factors and the reaction patterns against phages of two representative hybrids are summarized in Table 3 . All the 
Table 3. Antigen factors and phage sensitivity of parent strains and $\mathrm{His}^{+}$hybrids from the cross $\mathrm{Hfr} \mathrm{K} 9 \times \mathrm{FIO6 \textrm {I }}$

\begin{tabular}{|c|c|c|c|c|c|c|c|c|c|}
\hline \multirow{2}{*}{$\begin{array}{c}\text { Strain } \\
\text { no. }\end{array}$} & \multicolumn{5}{|c|}{ Action of phage* } & \multicolumn{4}{|c|}{$O$ factors } \\
\hline & P22 & $\mathrm{P} 22 \mathrm{c} 2$ & FO & $\mathrm{C}_{21}$ & $6 \mathrm{SR}$ & 4 & 5 & 9 & 12 \\
\hline Hybrids & & & & & & & & & \\
\hline $\mathrm{F} 1062$ & + & + & - & + & - & + & - & - & + \\
\hline FI069 & + & + & - & + & - & + & + & - & + \\
\hline Parents & & & & & & & & & \\
\hline F106I & + & + & - & + & - & - & - & + & + \\
\hline Hfrk9 & + & + & + & - & - & + & + & - & + \\
\hline
\end{tabular}

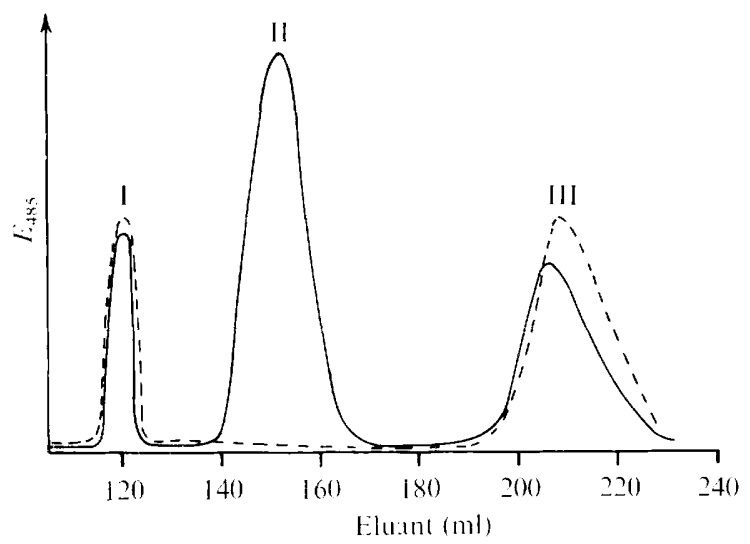

Fig. 3. Schematic presentation of the fractionation on Sephadex $\mathrm{G}_{50}$ of degraded polysaccharides obtained from E. coli hybrids F962 and $\mathrm{F} 970$ (- - ), and $\mathrm{F} 973$ and F98I (- - ). Eluant, pyridine acetate ( $10 \mathrm{ml}$ pyridine and $4 \mathrm{ml}$ glacial acetic acid/I, $\mathrm{pH} 5.4$ ); flow rate, $6 \mathrm{ml} /$ hour. Portions $(80 \mu \mathrm{l})$ were tested with the phenol-sulphuric acid reagent according to Dubois et al. (1955) and extinction was measured at $485 \mathrm{~nm}$.

other hybrids gave the same sensitivity patterns as shown in Table 3. The sensitivity towards phages $\mathrm{P}_{22}$ and $\mathrm{P}_{22 \mathrm{c} 2}$ indicates that the hybrids can synthesize the Salmonella O-specific polysaccharide chains which are required for the adsorption of these phages (Wilkinson et al., 1972).

The resistance to phage $\mathrm{FO}$ and the sensitivity towards phage $\mathrm{C}_{2} \mathrm{I}$ indicate the presence of the R I LPS core of E. coli $\mathrm{O} 8$ in the hybrids.

Fractionation of the lipopolysaccharides and analyses of the polysaccharide moieties

Degradation and gel permeation chromatography. From different representative hybrid strains lipopolysaccharides were extracted with a phenol-water mixture at $68{ }^{\circ} \mathrm{C}$ for 5 min (Lüderitz et al., I97I). All lipopolysaccharides were obtained in comparable yields (I to $2 \%$ ) and there were no differences observed during the extraction and work-up procedures.

The lipopolysaccharides were degraded with mild acid and the polysaccharide moieties were obtained by gel permeation chromatography on Sephadex G50. To make the various chromatographic runs directly comparable they were all performed on the same column $(2.5 \times 65 \mathrm{~cm})$. When polysaccharides from $E$. coli hybrids F962, F970, F973 and F98I (see Fig. I) 


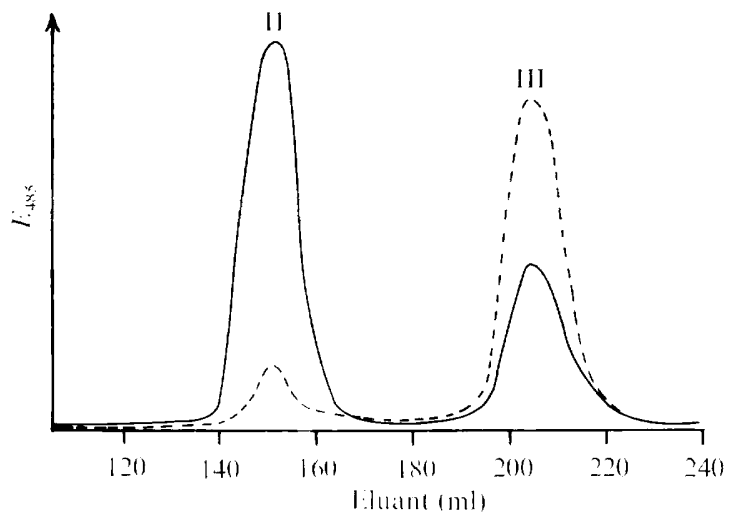

Fig. 4. Schematic presentation of the fractionation on Sephadex G5o of degraded polysaccharides obtained from hybrids F1008, FI061, 11062, F1063 and FI069 (- -), and F1009 (-- ). Details are given in the legend to Fig. 3 .

were chromatographed, the elution patterns shown in Fig. 3 were obtained. One peak (I) was always present. With F962 and F970 this was followed by a second peak (II) indicating material of somewhat smaller size which was missing in the elution pattern of F973 and F98I. Strains F973 and F98I had been derived from the O8-positive strains F962 and F970 by selection with the $E$. coli 08 phage $\Omega 8$ and resembled SR-forms of $S$. typhimurium. It can be surmised, therefore, that in the patterns of strains F962 and F970, peak II is due to O8polysaccharide derived from the $E$. coli O8 recipient. Peak III was present in all elution patterns and from its position it was expected to represent unsubstituted core oligosaccharide (Müller-Seitz et al., 1968; Schmidt et al., 1969).

The polysaccharide obtained from recombinants of S. typhi and E. coli O8 (FI008, FI009 and F106I) as well as those from recombinants obtained in crosses of Fro6I with the $S$. typhimurium donor Hfrk9 (FI062, FIO63 and FI069) were also analysed by gel permeation chromatography on Sephadex G50: their elution patterns are shown in Fig. 4. Peak I, which appeared in all patterns shown in Fig. 3, was missing in all patterns shown in Fig. 4. The significance of this is not yet known. Peaks II and III of Fig. 3 correspond to the first and second peak in Fig. 4, respectively. For better comparison the peaks in Fig. 4 are therefore also designated as peak II and peak III.

Analyses of polysaccharide moictics. The materials from the various peaks of the gel permeation chromatography were analysed as to their sugar components.

The results obtained with the recombinants derived according to scheme I (Fig. I) are shown in Table 4. In the first peaks only glucose was found. The corresponding material (PI) seems to be a glucan. The material from peak II (PII) of F962 and F970 consisted predominantly of mannose, and also contained galactose, glucose and heptose. In PII of F970 a small amount of glucosamine was also found. In F962 the molar ratios of galactose, glucose and heptose in PII were similar to those found in the E. coli R I core (Schmidt et al., I969), while in $\mathrm{F} 970$ (sensitive to phage FO; see Table 2) these molar ratios, together with the glucosamine value, approximated to the values found in the Salmonella core (Lüderitz et al. 1971). These analyses indicate that PII is a mannan terminating at the reducing end in a core oligosaccharide. Such a material is obtained after degradation of the LPS from E. coli O8 (Reske \& Jann, 1972).

Since F973 and F98I are $\Omega 8$ phage-selected strains they do not show a PII fraction. The PIIl fractions of all four recombinants contained mainly core components, their molar 
Table 4. Sugar composition of the peak materials obtained by gel permeation chromatography of the degraded polysaccharides from $S$. typhimurium $\times E$. coli recombinants

The values are expressed as percentages of the dry weight of each fraction.

LPS from:

$\begin{array}{cc}\text { Strain } & \text { Peak } \\ \text { F962 } & \text { I } \\ & \text { II } \\ & \text { III }\end{array}$

F970 I

$\begin{array}{ll} & \text { III } \\ \text { F973* } & \text { I } \\ & \text { III }\end{array}$

F981* II

$\begin{array}{cc}\text { Mannose } & \text { Rham } \\ 6 & \\ 66 \cdot 9 & \\ 9 \cdot 2 & \\ - & \\ 72 \cdot 1 & \\ 6 \cdot 6 & 4 \\ - & \\ 5 \cdot 7 & 5 \\ - & \\ 5 \cdot 4 & 4\end{array}$

Sugar composition

* As can be seen in Fig. 3, the elution patterns obtained with the R strains F973 and F98I lack peak II.

Table 5. Sugar composition of the peak materials obtained by gel permeation chromatography of the degraded polysaccharides from $S$. typh $\times$ E. coli recombinants (FI008, FI009, FI06I) and $(S$. typhi $\times$ E. coli) $\times$ S. typhimurium recombinants (FI062, FI063, FI069)

The values are expressed as percentages of the dry weight of each fraction.

LPS from:

$\begin{array}{ll}\text { Strain } & \text { Peak* } \\ \text { FI008 } & \text { II } \\ & \text { III } \\ \text { F1009 } & \text { II } \\ & \text { III } \\ \text { F106I } & \text { II } \\ & \text { III } \\ \text { FI062 } & \text { II } \\ & \text { III } \\ \text { F1063 } & \text { II } \\ & \text { III } \\ \text { FI } 069 & \text { II } \\ & \text { III }\end{array}$

Sugar composition

\begin{tabular}{|c|c|c|c|c|c|}
\hline Mannose & Rhamnose & $\mathrm{DDH}_{\dagger}^{\dagger}$ & Galactose & Glucose & Heptose \\
\hline $22 \cdot 9$ & $19 \cdot 2$ & $8 \cdot 7$ & $23 \cdot 9$ & $5 \cdot 5$ & $2 \cdot 3$ \\
\hline $4 \cdot 3$ & 54 & $1 \cdot 7$ & $14 \cdot 8$ & 13.5 & $21 \cdot 8$ \\
\hline ND & ND & $\mathrm{ND}$ & ND & ND & ND \\
\hline $5 \cdot I$ & $5 \cdot I$ & $2 \cdot 4$ & $17 \cdot 1$ & $I 6 \cdot I$ & 16.4 \\
\hline $21 \cdot 2$ & $18 \cdot 4$ & $8 \cdot I$ & $24: 3$ & $8 \cdot 5$ & 2.9 \\
\hline $4 \cdot 7$ & $5 \cdot 0$ & $x \cdot 7$ & $16 \cdot 6$ & I $6 \cdot 4$ & $22 \cdot 0$ \\
\hline $2 x \cdot 6$ & $18 \cdot 2$ & $7 \cdot 3$ & $23 \cdot 2$ & $5 \cdot 9$ & $2 \cdot 8$ \\
\hline $7 \cdot 8$ & $5 \cdot 5$ & $\mathrm{I} \cdot 8$ & $15 \cdot 6$ & $14 \cdot I$ & I $6 \cdot 9$ \\
\hline $2 x \cdot 2$ & $18 \cdot 4$ & $8 \cdot I$ & $24 \cdot 3$ & $5 \cdot 9$ & $2 \cdot 9$ \\
\hline $5 \cdot 7$ & $5 \cdot 0$ & $1 \cdot 7$ & $16 \cdot 6$ & I6.4 & $22 \cdot 0$ \\
\hline $23 \cdot 8$ & $20 \cdot 3$ & $10 \cdot 3$ & $25^{\circ} 9$ & $2 \cdot 8$ & 0.9 \\
\hline $5 \cdot 5$ & 5.5 & $2 \cdot 4$ & 15.9 & $14 \cdot 6$ & $10 \cdot 5$ \\
\hline
\end{tabular}

* Peak designation is such that Figs. 3 and 4 as well as Tables 4 and 5 are directly comparable.

$\uparrow \mathrm{DDH}, 3$, 6-dideoxyhexose; tyvelose in FI008, FI009 and F106I; abequose in FI062, FI063 and FI069.

ratios indicating an $E$. coli $\mathrm{R}$ I structure in F962 and F973 and a Salmonella core structure in F970 and F981. In addition, they all contain equimolar amounts of mannose and rhamnose, and smaller amounts of abequose. Due to the volatility of their alditol acetates, dideoxyhexoses are partially lost in gas-liquid chromatography. Therefore, it is reasonable to assume that in the PII fractions mannose, rhamnose and abequose were present in equimolar amounts. This is corroborated by the value of galactose, which was higher than expected for the corresponding core ratios by amounts which were about equal to the values of mannose and rhamnose. These results indicate that the PIII fractions are mixtures of unsubstituted core oligosaccharides and core oligosaccharides substituted with one repeating unit (Abe, Gal, Man, Rha) of the S. typhimurium polysaccharide; thus, recombinants F962 and F970 are 
S-forms with an $E$. coli $\mathrm{O} 8$ polysaccharide, and additionally are SR-forms with respect to S. typhimurium.

The results obtained with recombinants derived according to scheme 2 (Fig. 2) are shown in Table 5. None of the strains produced a glucan. With FI009, too little PII material was found to be analysed. Analogous to the above reasoning, the values found can be interpreted in the following way: the PIII fraction of Froog, according to its analysis, is a core oligosaccharide of the $E$. coli R I type substituted with one repeating unit of the $S$. typhi polysaccharide. In FI008 and FI06I, the PII fraction is the polysaccharide of S. typhi (with tyvelose), terminating at the reducing end in the $E$. coli R I core oligosaccharide. The PIII fraction is the core substituted by a $S$. typhi repeating unit. In FI062, FI063 and FI069 the same situation was found, in PII the polysaccharide being that of $S$. typhimurium (with abequose) and in PIII the core being substituted with one repeating unit of the S. typhimurium polysaccharide.

All strains analysed also contained unsubstituted core stubs, which explains the asymmetric shape of peak III in Figs. 3 and 4.

\section{DISCUSSION}

Genetic crosses between $S$. typhimurium Hfrk9 and an $E$. coli O8 recipient generated $\mathrm{His}^{+}$hybrids expressing both Salmonella and $E$. coli $\mathrm{O} 8$ specificities. This suggested that the $r f b$ gene clusters of both mating partners are functional in these hybrids.

The partial diploid state, apparently stably maintained in the hybrids, may have generated from the insertion of donor genes at novel sites of the recipient chromosome, thus leading to a duplication of the his-rfb region (Baron et al., I968; Mojica-a \& Middleton, 1972). Alternatively, the transferred donor DNA may be conserved quite stably in an extrachromosomal state. Studies are in progress on the mechanism maintaining partial diploidy in these hybrids.

In crosses between $S$. typhi donor WR4000 and E. coli O8, smooth $\mathrm{His}^{+}$recombinants were obtained which had lost the E. coli O8 antigen and only expressed the S. typhi O9,I2 specificity. In this case the $r f b$ region of the donor must have replaced that of the recipient by recombination, thus producing haploid recombinants. Similarly, Johnson \& Baron (I969) reported that a high portion of $E$. coli recombinants from crosses between $S$. typhi donor WR4000 and $E$. coli were haploid for several allelic regions transferred from the donor.

Escherichia coli $\mathrm{O} 8$ acquires the $r f_{c}$ locus in crosses with $S$. typhi but not in crosses with $S$. typhimurium. This, and the fact that $S$. typhi imposes haploidy and $S$. typhimurium diploidy in the $r f b$ region of the recombinants, cannot be explained at present.

The smooth and semi-rough $\mathrm{His}^{+}$recombinants exhibiting $S$. typhimurium O-specificity synthesize O-antigen factors $4,(5)$ and 12 . Factor I2 of $S$. typhimurium is complex and divided into sub-factors $12_{1}$ and $12_{2}$ (Kauffmann, 1966). The chemical nature of $12_{1}$ is not known but rhamnose in the polysaccharide chain is supposed to be involved in the $\mathrm{I}_{2}$ specificity (Staub et al., 1959). The results of our serological tests suggest the absence of the factor $12_{2}$ in the recombinants. The genes (oaf $R, E, F$ ) responsible for glucosylation of the polysaccharide resulting in $\mathrm{I}_{2}$ specificity are located near purE and remote from the his-rfb region (Rudén \& Mäkelä, 1974). This explains the lack of Or $2_{2}$ specificity in the hybrids selected here.

The serological findings and bacteriophage patterns obtained were fully corroborated by chemical analyses. Hybrids between $S$. typhimurium and E. coli $\mathrm{O} 8$ (F962 and F970) exhibited on their surface complete O8 S-lipopolysaccharide, the polysaccharide moiety of which is a 
mannan consisting of 20 to 22 trisaccharide units (Reske \& Jann, 1972). In addition, they synthesize a $S$. typhimurium-specific SR-lipopolysaccharide which is a core oligosaccharide substituted by one $\mathrm{O}$-specific repeating unit consisting of abequose, mannose, rhamnose and galactose (Lüderitz et al., I97I). Most of the recombinants [of which $\mathrm{F962}$ and F973 (O8-) are representative] contain the $E$. coli R I core, and one hybrid (F970) and its O8-negative derivative (F98I) contain the Salmonella core, obviously in consequence of the introduction of donor $r f a$ genes. These core types can easily be differentiated by their sugar composition: the $E$. coli Ri core does not contain glucosamine and has a glucose: galactose ratio of $3: 2$ (Schmidt et al., 1969), whereas the Salmonella core contains glucosamine, glucose and galactose in molar ratios of $1: 2: 2$ (Lüderitz et al., 1971).

Recombinants of $S$. typhi and E. coli O8 (FI008, FI009 and FI06I) exhibited only $S$. typhi-specific lipopolysaccharides. Degradation and gel permeation chromatography gave rise to (i) fractions containing core oligosaccharide substituted with a polysaccharide consisting of approximately 20 tetrasaccharide units containing tyvelose, mannose, rhamnose and galactose, and (ii) fractions containing core oligosaccharide substituted with only one such oligosaccharide. Thus, recombinants FI008, FI009 and F106I synthesize S- and SR-lipopolysaccharides of the same specificity, concomitantly. The relative ratios of these surface antigens differed in these strains, strain FIO09 producing predominantly SRlipopolysaccharide and strains FI008 and FI06I producing predominantly S-lipopolysaccharide. The polysaccharides did not contain glucose; this can be explained by the obvious lack of the oafR,E,F-modification (glucosylation) genes in the recombinants.

When in a subsequent cross the ( $S$. typhi-specific) $r f b$ locus of recombinant FI06I was replaced by the (S. typhimurium-specific) $r f b$ locus of Hfrk9 (see Fig. 2), the ensuing recombinants FI062, FI063 and FI069 produced S- and SR-lipopolysaccharides which contained abequose instead of tyvelose.

Recombinants between E. coli O8 (F210) and S. typhimurium contained a glucan, and all other recombinants did not. The reason for this is not known. Possibly, the information for the synthesis of this glucan may be determined by the $E$. coli strain, because this strain (F210) is a different isolate of E. coli O8 than the one (F464) used in the other mating experiments. We have found previously (Jann and Jann, unpublished observations) that many $E$. coli strains synthesize such a glucan. Of special biochemical interest is the concomitant occurrence of S-, SR- and R-lipopolysaccharides in one bacterial strain. This phenomenon was also observed in $E$. coli wild-type strains which produced acidic lipopolysaccharides (Jann and Jann, unpublished observations).

We are greatly indebted to Dr L. S. Baron, Washington, D.C., and Dr K. Sanderson, Calgary, for supplying Salmonella donors. The excellent technical assistance of Miss $U$. Fischer, Mrs A. Gutmann and Miss C. Heidkämper is gratefully acknowledged. This work was supported by the Deutsche Forschungsgemeinschaft.

\section{REFERENCES}

Adams, M. H. (1959). Bacteriophages, pp. 46I-469. New York: Interscience Publishers.

Baron, L. S., Gemski, P., Johnson, E. M. \& Wohlhieter, J. H. (I968). Intergeneric bacterial mating. Bacteriological Reviews 32, 362-369.

Dubois, M., Gilles, K. A., Hamilton, J. K., Rebers, P. A. \& Smith, F. (1955). Colorimetric method for determination of sugars and related substances. Analytical Chemistry 28, 350-356. 
Hämmerling, G., Lüderitz, O., WestPhal, O. \& Mäkelä, P. H. (I97I). Structural investigations on the core polysaccharide of Escherichia coli () 100. European Journal of Biochemistry 22, 33I-344.

Holme, T., Lindberg, A. A., GaregG, P. J. \& OnN, T. (1968). Chemical composition of cell wall polysaccharides of rough mutants from Salmonella typhimurium. Journal of General Microbiology 52, 45-54.

JanN, K., Schmidt, G., Wallenfels, B. \& Frfund-Mölbert, E. (1971). Isolation and characterization of Escherichia coli bacteriophage $\Omega 8$ specific for E. coli strains belonging to sero-group O8. Journal of General Microbiology 67, 289-297.

Johnson, E. M. \& BARON, L.S. (1969). Genetic transfer of the Vi antigen from Salmonella typhosa to Escherichia coli. Journal of Bacteriology 99, 358-359.

Johnson, E. M., Falkow, S. \& Baron, L. S. (1964). Chromosome transfer kinetics of Salmonella Hfr strains. Journal of Bacteriology 88, 395-400.

Jones, R. T., Koeltzow, E. E. \& Stocker, B. A. D. ( 1972 ). Genetic transfer of Salmonella typhimurium and Escherichia coli lipopolysaccharide antigens to Escherichia coli K I2. Journal of Bacteriology III, 758770.

Kallings, L. O. (1967). Sensitivity of various Salmonella strains to Felix O-I phage. Acta pathologica et microbiologica scandinavia 7o, 446-460.

Kauffmann, F. (1966). The Bacteriology of Enterobacteriaceae. Copenhagen: Munksgaard.

KAY, D. (1962). The nucleic acid composition of bacteriophage $\phi$ R. Journal of General Microbiology 27 , $20 I-207$.

KIEFER, W. (1974). Salmonella typhimurium- Escherichia coli Rekombinanten. Thesis, Freiburg University.

Lindberg, A. A. (1967). Studies of a receptor for Felix O-I phage in Salmonella minnesota. Journal of General Microbiology 48, 225-233.

LindberG, A. A. ( 1973). Bacteriophage receptors. Annual Review of Microbiology 27, 205-24l.

Lüneritz, O., Westphal, O., Staub, A. M. \& Nikalio, H. (1971). Isolation and chemical and immunological characterization of bacterial lipopolysaccharides. In Microbial Toxins, vol. 4, pp. 145-224. Edited by G. Weinbaum, S. Kadis and S. J. Ajl. New York: Academic Press.

Mäkel.̈, P. H. (1965). Inheritance of the O antigens of Salmonella groups B and D. Journal of General Microbiology 4I, 57-65.

M ̈̈KEL ̈̈, P. H. (1966). Genetic determinants of the $\mathrm{O}$ antigens of Salmonella groups $\mathrm{B}(4,5,12)$ and $\mathrm{C}_{2}(6,7)$. Journal of Bacteriology 91, I I I 5-I I 25.

MÄKEL $\ddot{A}$, P. H. (1973). Glucosylation of lipopolysaccharide in Salmonella mutants negative for $\mathrm{O}$ antigen factor $12_{2}$. Journal of Bacteriology $116,847-856$.

MAYER, H. \& SCHMIDT, G. ( I973). The occurrence of three different lipopolysaccharide cores in Shigella and their relationship to known enterobacterial core types. Zentralblatt fiir Bakteriologie, Parasitenkunde, Infecktionskrankheiten und Hygiene (Abteilung I) 224, 345-354.

Mojica-A, T. \& Middleton, R. B. (1972). Salmonella typhimurium-Escherichia coli hybrids for the tryptophan region. Genetics $7 \mathbf{I}, 49 \mathrm{I}-505$.

Müller-Seitz, E., JANN, B. \& JANN, K. (1968). Degradation studies on the lipopolysaccharide from E. coli $\mathrm{O}_{71}: \mathrm{K}$ ?: $\mathrm{H}_{12}$. Separation and investigation of $\mathrm{O}$-specific and core polysaccharide. FEBS Letters I, 3 I I-3 I 4 .

$\emptyset_{\mathrm{RSKOV}}, \mathrm{F}$. \& ØRSKov, I. (I962). Behaviour of Escherichia coli antigens in sexual recombination. Acta pathologica microbiologica scandinavia 55, 99-109.

RESKE, K. \& JANN, K. (1972). The O8 antigen of Escherichia coli. Structure of the polysaccharide chain. European Journal of Biochemistry 31, 320-328.

RUdÉN, U. \& MäKELÄ, P. H. (1974). O-Acetylation and glucosylation of lipopolysaccharide in hybrids between Salmonella groups B and $C_{2}$. Europe'un Journal of Biochemistry 48, I I-20.

Sanderson, K. E., Ross, H., Ziegler, L. \& MäKflä, P. H. (1972). F', Hfr and $F^{\prime}$ strains of Salmonella typhimurium and Salmonella abony. Bacteriological Reviews 36, 608-637.

Schlecht, S. \& WestPhal, O. (1966). Wachstum und Lipopolysaccharid (O-Antigen)-Gehalt von Salmonellen bei Züchtung auf Agarnährböden. Zentralblatt fïr Bakteriologie, Parasitenkunde, Infecktionskrankheiten und Hygiene (Abteilung I) 200, 241-259.

SchmidT, G. (1973). Genetical studies on the lipopolysaccharide structure of Escherichia coli K12. Journal of General Microbiology 77, I $5 \mathrm{I}-160$.

ScHmidt, G., JANN, B. \& JANN, K. (1969). Immunochemistry of R lipopolysaccharides of Escherichia coli. Different core regions in the lipopolysaccharides of $\mathrm{O}$ group 8. European Journal of Biochemistry Io, $50 \mathrm{I}-5 \mathrm{IO}$.

Schmidt, G., JANN, B. \& JANN, K. (1970). Studies on R mutants with an incomplete core, derived from Escherichia coli O8: K27. European Journal of Biochemistry 16, 382-392.

SChmidT, G., JANN, B. \& J ANN, K. (1974). Genetic and immunochemical studies on Escherichia coli O14: $\mathrm{K}_{7}: \mathrm{H}^{-}$. European Journal of Biochemistry 42, 303-309.

Staub, A. M., Tinelli, R., Lüderitz, O. \& Westphal, O. (1959). Rôle de quelques sucres et en particulier des 3,6-didesoxyhexoses dans la spécificité des antigènes $\mathrm{O}$ du tableau Kauffmann-White. Annales de l'Institut Pasteur 96, 303-332. 
StoCKER, B. A. D. \& MÄKELÄ, P. H. (1971). Genetic aspects of biosynthesis and structure of Salmonella lipopolysaccharide. In Microbial Toxins, vol. 4, pp. 369-433. Edited by G. Weinbaum, S. Kadis and S. J. Ajl. New York: Academic Press.

Strominger, J. L., Park, T. J. \& Thompson, R. E. (1959). Composition of the cell wall of Staphylococcus aureus: its relation to the mechanism of action of penicillin. Journal of Biological Chemistry 234, 32633368.

Waravdekar, V. S. \& SaSlaw, L. D. (1959). A sensitive colorimetric estimation of 2-deoxysugars with use of the malonaldehydethiobarbituric acid reaction. Journal of Biological Chemistry 234, 1945-1950.

Wilkinson, R. G., Gemski, P. \& Stocker, B. A. D. (1972). Non-smooth mutants of Salmonella typhimurium. Differentiation by phage sensitivity and genetic mapping. Journal of General Microbiology 7o, 527-554.

ZINDER, N. D. (1953). Infective heredity in bacteria. Cold Spring Harbor Symposia on Quantitative Biology I8, 26I-269. 